\title{
Retranslations of Faulkner's Sanctuary in Turkish Literature
}

\author{
Gülsüm Canl1 ${ }^{1, *}$, Ayşe Banu Karadağ ${ }^{2}$ \\ ${ }^{1}$ School of Foreign Languages, Istanbul University, Turkey \\ ${ }^{2}$ Department of Translation and Interpreting (French), Ylldiz Technical University, Turkey \\ Corresponding Author: Gülsüm Canl1, E-mail: canligulsum@gmail.com
}

\section{ARTICLE INFO \\ Article history \\ Received: March 16, 2018 \\ Accepted: May 01, 2018 \\ Published: June 30, 2018 \\ Volume: 9 Issue: 3 \\ Advance access: January 2018}

Conflicts of interest: None

Funding: None

\begin{abstract}
This study is based on a comparative analysis of Turkish translations of Sanctuary (1931) by William Faulkner and aims to review the assumptions of literary translation by Antoine Berman's "retranslation hypothesis" and "deforming tendencies". The novel was exposed to an obligatory rewriting process by the editor and was reworded by Faulkner who acted as a self-translator to make the original version acceptable. The rewritten version, which can be regarded as an intralingual translation, became the source text for interlingual translations. The novel was first translated by Ender Gürol as Kutsal Siğınak (1961); then by Özar Sunar as Lekeli Günler (1967) and finally by Necla Aytür as Tapınak (2007). Among Faulkner's fifteen books which have been translated into Turkish thus far, Sanctuary is the only one with three translations in total. The translational process will be described to understand the rationale behind translators' decisions within the context of translation studies.
\end{abstract}

\section{Key words:}

Literary translation,

Retranslation,

Deforming tendencies.

\section{INTRODUCTION}

A text cannot be understood in isolation from its context because texts are written according to the poetics of their time and setting. In cases where authors diverge from poetics, they either ignore the reactions at the expense of being excluded and marginalized or they reach an agreement for the sake of being approved and published. What happened to the novel Sanctuary (1931) by William Faulkner (1897-1962) within the American Literature is an example of this literary deal. Nobel Prize winner William Faulkner was requested to rewrite his novel Sanctuary because the original version of the text was found unpublishable by the editor who foresaw a possible jail sentence for Faulkner and himself. Faulkner agreed to rewrite his work thinking that he might earn some money if it sold a few thousand copies. The outcome of the rewriting was beyond Faulkner's expectations and Sanctuary became a corner stone in his career and gained a sensational reputation in the source culture. Its reputation exceeded the source culture, and the novel was translated into several languages such as French, Spanish, German, Portuguese, Danish, Italian, Norwegian, Swedish, Japanese and Turkish.

Within the scope of translation studies, literary translation has always been an important research area, and in the context of literary translation, retranslations have always been one of the essential research topics because retranslation is a common phenomenon with various discussion points. The aging of translations, the inadequacy of the former translations, increasing knowledge about the source culture, text and author and the idea of addressing a new readership are seen as the main reasons for retranslation. Although these reasons may explain several cases, the complexity of retranslation is not totally resolved.

This paper is restricted to three Turkish translations of Sanctuary. As the only William Faulkner novel, which has been translated into Turkish language three times, Sanctuary requires closer attention. The source text was first translated by Ender Gürol as Kutsal Siğınak in 1961. The second translation was carried out by Özar Sunar as Lekeli Günler and published in 1967. And the most recent version was translated by Necla Aytür as Tapınak in 2007. The study will be based on the concept of "translation as the trial of the foreign' suggested by the French scholar Antoine Berman. According to this concept, for a receiving culture, a source text would always be unusual and foreign. Berman suggests a list of twelve deforming tendencies to overcome this peculiar encounter between the source text and the target culture. These twelve deforming tendencies will be the guide for the comparative textual analysis. In this paper, first, we aim to see how the source text has been retranslated to make it acceptable for a second and third time. Also, the translators' awareness of deforming tendencies will be understood via the textual comparison. Finally, the effects of deforming ten- 
dencies on the translated texts will be analyzed in an attempt to see the end result of each translation process.

\section{A BRIEF LOOK AT AN ACT OF REWRITING WITHIN THE SOURCE CULTURE}

The novel Sanctuary was described as 'a cheap idea' by Faulkner himself 'because it was deliberately conceived to make money' (Faulkner 1931: v). In order to write 'the most horrific tale' he could imagine, Faulkner came up with a story line.

I began to think of books in terms of possible money. I decided I might just as well make some of it myself. I took a little time out, and speculated what a person in Mississippi would believe to be current trends, chose what I thought was the right answer. (Faulkner 1931: vi)

His efforts to write a text did not pay off at first because the publisher rejected it claiming that they would both be in jail if it were published (cf. Faulkner 1931: vi). The manuscript which was later accepted for publication was a rewritten version of the first draft as it had been seriously edited by the publishing company. Faulkner wrote the 'how's and 'why's of the rewriting process as:

I think I had forgotten about Sanctuary, just as you might forget about anything for an immediate purpose, which did not come off. As I lay Dying was published and I didn't remember the mss. of Sanctuary until Smith sent me the galleys. Then I saw that it was so terrible that there were but two things to do: tear it up or rewrite it. I thought again, "It might sell; maybe 10,000 of them will buy it." So, I tore the galleys down and rewrote the book. It had been already set up once, so I had to pay for the privilege of rewriting it, trying to make out of it something which would not shame The Sound and the Fury and As I Lay Dying too much and made a fair job and I hope you will buy it and tell your friends and I hope they will buy it too. (Faulkner 1931: vii-viii)

In the revised version, the story, which takes place in the Prohibition era, is about a seventeen-year-old, college student, Temple Drake. Being a member of a good family and the daughter of a judge does not hinder her from enjoying her youth. One night, she goes on a date with Gowan Stevens, a local bachelor who is proud of having received a university education in Virginia. The couple agree to meet the following morning to go to a baseball game with Temple's classmates by train but Gowan passes out in his car as he keeps drinking heavily the whole night. Still drunk, he catches the train and persuades Temple to violate the school rules and join him in his car to go and see the game. On the way, Gowan decides to stop by the Old Frenchman Place, a distillery, because he wants to continue drinking. There, Temple is raped and one of the employees, Tommy is killed. Afterwards, she is abducted by her rapist, Popeye, and brought to a brothel. Later in the story, the landlord of the Old Frenchman Place, Lee Goodwin, is accused of murdering Tommy. Horace Benbow, who, by chance, passes by Goodwin's place and meets them on his way to his hometown before the murder and rape take place, wants to defend Lee Goodwin and help his wife Ruby. He finds Temple and believes that she would help to prove Lee's innocence. However, her statement, which is reshaped at the court, leads to Lee's death.

Scholars express different opinions as to why Faulkner felt the need to revise the original text for publication ${ }^{1}$. Some scholars believe that the text was revised "not because it was immoral but because it was artistically flawed". They claim that the story line is basically the same in both versions (Phillips 1988:66). However, there are others who do not believe that the published version outperforms the original text. The editor of the book Sanctuary: The Original Text finds the original text "highly serious with an integrity all its own" (Jaillant 2016: 142).

Despite the disagreement about the reasons for rewriting, it is possible to agree on its purpose. André Lefevere suggests that "all rewritings, whatever their intention, reflect a certain ideology and a poetics and as such manipulate literature to function in a given society in a given way" (1992: vii). Therefore, it is possible to say that Faulkner had to revise and re-contextualize and perhaps even naturalize his work so that it would be acceptable for the source culture. With reference to Lefevere, Esra Birkan-Baydan suggests that “... any textual/communicative practice whether it be translating or editing, is an act of rewriting" and offers to create an awareness of this relation as she believes that "translation studies can be of help to editorial practices" (2011: n. pag).

Faulkner's editing experience can be associated with translating. The rewriting experience Faulkner had under editorial constraints reminds us of the translating experience any translator would face in the literary domain. As Faulkner moves towards being a self-translator, his revised version can be regarded as an intralingual translation. Intralingual translation or rewording is defined as "an interpretation of verbal signs by means of other signs of the same language" (Jakobson 1959: 233). Taking Jakobson's definition into consideration, we can say that the original text of Sanctuary, which was reworded by the author himself, underwent the process of intralingual translation.

After having a brief look at the rewriting process in the source culture, this paper will continue the discussion by focusing on the translations of the source text into Turkish. The study limits itself with the comparative textual analysis of three Turkish translations of Sanctuary to understand what has happened with each rewriting in terms of "deforming tendencies" (cf. Berman 2000).

\section{THEORETICAL FRAMEWORK}

The French translation scholar Antoine Berman mentions two categories when it comes to the division of the entire field of translation: "literary" vs. "non-literary". According to him, non-literary translations perform only a semantic transfer and have exterior and instrumental relations to their language. However, in the literary domain, the connection between the text and the language is much more powerful, which leads to a collision between two languages. Within this category, Berman criticizes the functions translation undertakes such as "negation, acclimation and naturalization" because he believes that translation will be ethical providing the Foreign is received as the Foreign (Berman (tr. Venuti), 2000: 285-286). 
Berman defines translation as "the trial of the foreign", which occurs in a double sense:

In the first place, it establishes a relationship between the Self-Same (Propre) and the Foreign by aiming to open up the foreign work to us in its utter foreignness. [...] In the second place, translation is a trial for the Foreign as well, since the foreign work is uprooted from its own language-ground (sol-de-langue). And this trial, often an exile, can also exhibit the most singular power of the translating act: to reveal the foreign work's most original kernel, its most deeply buried, most self-same, but equally the most "distant" from itself (Berman (tr. Venuti), 2000: 284).

The idea of 'translation as the trial of the foreign' which was suggested by Antoine Berman, will be the basis for our research and we will make use of Berman's twelve deforming tendencies as a guideline to see how the foreign source text has been handled in the target culture. In order to avoid the trial of the foreign, Berman suggests an analysis of textual deformation. He believes that such an analysis will lead to an awareness that will free translators from the system of deformation (Berman (tr. Venuti), 2000: 286). He makes a list of twelve tendencies in question:

1. rationalization

2. clarification

3. expansion

4. ennoblement and popularization

5. qualitative impoverishment

6. quantitative impoverishment

7. the destruction of rhythms

8. the destruction of underlying networks of signification

9. the destruction of linguistic patternings

10. the destruction of vernacular networks or their exoticization

11. the destruction of expressions and idioms

12. the effacement of the superimposition of languages (Berman (tr. Venuti), 2000: 288).

When the tendencies mentioned above were taken into consideration, binary oppositions - 'good vs. bad'- were used in the analysis of translations at first. A translation with a domestic attitude was thought to be 'bad' because it negated the foreignness while a good translation was believed to appreciate "the foreignness of the foreign text" (Berman 1992, in Venuti 1999:81). However, later Berman became more flexible in this restrictive binary assessment and recognized that "a domesticating translator can't simply be dismissed as unethical" provided that the translator's decisions are explained in the preface and notes (Berman 1995, in Venuti 1999: 81). Berman also argues that translation, by its nature, is incomplete and each retranslation is better than the previous version (cf. Berman 1990). Therefore, it is possible to say that former translations would have more examples of 'deforming tendencies' than the latter translations.

In this paper, we are mainly concerned with the examples of 'deforming tendencies' to see the process that the source text has gone through with each translation. While comparing three translations of Sanctuary, we aim to understand the use of 'deforming tendencies' while translating the source text into the target culture and literary polysystem.

\section{THE TRANSLATIONS OF SANCTUARY INTO THE TURKISH LITERARY SYSTEM}

There are three Turkish translations of the book in circulation. The first one called Kutsal Siğınak which can be literally translated as Holy Shelter was rendered in $1961^{2}$ by Ender Gürol who worked as an academic at the Department of Translation and Interpreting Studies at Boğaziçi University. He also worked as a translator for NATO and co-wrote Çağdaş Işs Dünyası Sözlüğü (Dictionary for Modern Business Life) in addition to being a member of PEN Writers Association. Sanctuary is his first translation and he mostly translates novels and theoretical books on psychology. The second one, called Lekeli Günler, which can be literally translated as Stained Days was rendered in 1967 by Özar Sunar who has translated several books by authors such as Agatha Christie, John Steinbeck, Harper Lee, Howard Fast and Catherine Gaskin. The most recent, called Tapınak, the literal translation for Temple, was translated in 2007 by Necla Aytür. She worked in the Department of American Literature at both Minnesota and Yale Universities. She also wrote her associate professorship dissertation on Faulkner and retired from the Department of American Culture and Literature at Ankara University.

Although the translators' personal and the publishers' corporate motives are not clear for the first translation and retranslations, it is possible to say that William Faulkner has gained a certain degree of popularity among Turkish readers considering the fact that more than fifteen of his novels \& stories have been translated thus far with several reprints. Bearing in mind the fact that Sanctuary is Faulkner's only novel with two retranslations into Turkish, it was decided that a closer inspection was necessary and the first thing that attracted our attention and encouraged us to carry out detailed research was the translation of the title ${ }^{3}$.

The word 'sanctuary' has the following meanings ("sanctuary").

1. protection or a safe place, especially for someone or something being chased or hunted

2. a place where birds or animals can live and be protected, especially from being hunted or dangerous conditions

3. the most holy part of a religious building.

According to Hal McDonald, this ironic title refers to many sources of 'sanctuary' in Faulkner's novel. For example, the small wooden box where Ruby keeps the baby at the Old Frenchman Place is a sanctuary for the baby as the mother believes that she needs to protect him against the mice. Lee Goodwin refuses to give evidence against Popeye and prefers to stay in jail because he believes that if he testifies and Popeye is found guilty, he will be killed outside the jail anyway. Thus, the jail functions as Lee's sanctuary where he is protected against Popeye's possible assault. However, neither of these sanctuaries protected these two characters. The baby became sick and Ruby felt obliged to get help from a doctor. Although she tried 
her best to protect her child from rats, she could not deal with the sudden sickness. And Lee was not harmed by Popeye, as Popeye was in jail in Alabama, but sentenced to death due to the corruption of the judicial system as Temple testified against him (1997: 222-223). Lee did not live long enough to suffer his punishment as he was lynched. In short, the title was ironic for both characters and their sanctuaries could not protect them against the dangers they could foresee because things turned out in a way they could not have predicted.

As a runaway husband (Irwin 1992: 544), Horace is in search of a sanctuary as well. He runs away from his wife and his step-daughter because, while he has no feelings for his wife, he seems to have problems in controlling his desire for Little Bell. For this reason, he insists on living alone in an old, abandoned house and goes back to the safety and security of his homeland (Urgo 1983: 441). The irony of protection against danger follows Horace in his sanctified home town when he decides to defend Lee Goodwin. After people lynch Goodwin, Horace has to accept his failure and goes back to his wife and Little Bell. He leaves because he does not want to cause any trouble. In short, his search for a sanctuary ends in failure.

Based on the evaluations above, it is not possible to say that Faulkner might have used the word 'sanctuary' loosely (Urgo 1983:443). Considering the meaning of the title in the source text, we will see whether the translated titles encompass all these meanings and functions.

The title of T1, 'Kutsal Siğınak' (Holy Shelter), is quite close to the third meaning of the word 'sanctuary' however holiness is not among the functions emphasized in the title in the source text. T2 entitled 'Lekeli Günler' (Stained Days) reminds the reader of the stained cob displayed at the court where the blame was put on Goodwin. As Popeye is impotent, he uses the cob to rape Temple. With such a specific reference to the offensive weapon, T2 fails to evoke the irony of the original title. The title of T3, 'Tapinak'(Temple), is explained by the translator in the preface:

While, the concept of womanhood, which is the symbol of virtue and beauty, was holy in the traditional South, the woman of the 'new' South is Temple who is far from the meaning of her name. Temple is a girl without hips and boobs but with lots of make-up and defiant looks. She acts in a childish and irresponsible way. Either she is not aware of the fact that she harms the people around her or she does not care about it. (Aytür 2007: 7, our translation)

Aytür's translation is the only one with a preface and the translator acts as a literary critic who informs the reader about what to expect from the book. The above paragraph taken from her preface realizes two of the possible functions attributed to prefaces": "promoting understanding of the source culture" and "promoting understanding of the translator's role and intervention" (McRae 2010: 20).

Prefaces and translator's notes have been the subject of much research ${ }^{5}$. In this case, besides giving information about the source culture by explaining the image of womanhood in the South, the preface contributes to our attempt to understand Aytür's decision about the translation of the title.
By translating the title as Tapinak (Temple), she took the irony of the source text culture into consideration. The concept of womanhood is evolving in the South and this evolution is full of irony. Temple sets a very good example of this irony as a female character. She is the image of the new woman of the South. Physically, she is no different from a child as her body is not yet fully developed. However, society regards her as a woman and she tries to underline this socially constructed image by putting on make-up and adopting a feminine style. However, with the title 'Tapinak', the irony of the Southern culture is still restricted to only Temple.

The density of the meaning given through the ironic title of the source text cannot be found in any of the translations and this tendency can be rendered as a qualitative impoverishment. To clarify this deforming tendency Berman gives the example of a butterfly:

[...] This does not mean that the word "butterfly" objectively resembles "a butterfly," but that in its sonorous, physical substance, in its density as a word, we feel that it possesses something of the butterfly's butterfly existence (Berman (tr. Venuti), 2000: 291).

The qualitative impoverishment, which has been exemplified in the translation of the title as a deforming tendency, encouraged us to question what other decisions have been taken within the three translated texts. Other deforming tendencies will be exemplified in the following chapters to generate an idea about how these decisions affect the translations.

\section{A COMPARATIVE ANALYSIS OF SANCTUARY AND ITS TURKISH TRANSLATIONS}

\section{A) Rationalization}

This deforming tendency is mainly concerned with syntax. Punctuation, reordering the sentence sequence or dividing the sentences are regarded as ways of rationalization. Berman thinks that rationalization leads to abstraction, for example, when a verb is translated with a noun. It also destroys the imperfect nature of the prose, which Berman believes is a condition of its existence (2000: 288-289). The tendency to generalize during translation is also thought to be an example of rationalization (Munday 2001:147).

Example 1:

ST: There are so many of them (Faulkner 1931: 62)

T1: Amma da insan bolluğu var burada (Faulkner (tr. Gürol) n.d.: 36)

T2: Burada o kadar çok insan var ki (Faulkner (tr. Sunar) 1967: 55)

T3: O kadar çok adam var ki (Faulkner (tr. Aytür) 2007: 48)

This example is taken from a conversation between Temple and Ruby on the night when Temple and Gowan arrived at the Old Frenchman Place after the accident. The two women smoke their cigarettes in the kitchen and Temple tries to be optimistic believing that the men in the house would not harm her as there are many of them. Indeed, Temple thinks aloud while uttering this sentence and the reader can follow her stream of consciousness. In T1 and T2, the pronoun 'them' has been translated as 'insan' 
(people) although it specifically refers to men within the context of the source text. T3 is the only translation that helps the reader hear Temple's inner voice.

Example 2:

ST: Boys will be boys, wont they? (Faulkner 1931: 248)

T1: İnsanlar hep bir, değil mi? (Faulkner (tr. Gürol) n.d.: 129)

T2: İnsanlar her yerde insandır, değil mi? (Faulkner (tr. Sunar) 1967: 187)

T3: Erkek ne de olsa erkektir, deel mi? (Faulkner (tr. Aytür) 2007: 163)

This sentence was uttered by Senator Snopes when Horace was about to enter Miss. Reba's brothel to talk to Temple. Snopes is the kind of man familiar with brothels, in fact, he knows a lot about such places. Based on his personal experience and perception, he thinks that Horace would go into a brothel for the same reason he does and he believes that this is normal for men. He is uttering this sentence to make Horace feel that his secret is safe with him. But actually, he is aware of the fact that Horace is there to visit Temple because Snopes is the person who informed Horace about Temple's whereabouts. Still, he does not miss the opportunity to make Horace feel uncomfortable.

As in Example 1, T1 and T2 translate 'boys' as 'insanlar' (people) while T3 gives the source text meaning by translating 'boys' as 'erkekler' (male). This conversation is not about being human. It is about being a man and having manly habits. The generalization in $\mathrm{T} 1$ and $\mathrm{T} 2$ miss this point.

B) Clarification

This tendency is mostly observed as a result of rationalization. The vague language in the source text becomes definite in the target text. Berman agrees that translation tends to be more explicit by its nature but he warns against revealing the intentionally hidden meaning in the original (2000: 289).

Example 3:

ST: That was the only part of the whole experience which appeared to have left any impression on her at all: the night which she had spent in comparative inviolation. (Faulkner 1931: 258)

T1: Olayın yalnızca bu bölümü sanki, etkilemişti onu, kimsenin doğrudan doğruya saldırıya uğramadan geçirdiği gece. (Faulkner (tr. Gürol) n.d.: 134)

T2: Kimsenin kendisine tecavüz etmediği o geceden kalan izler sadece bunlard1 sanki. (Faulkner (tr. Sunar) 1967: 194)

T3: Başından geçen şeylerden yalnız bu bölümü onun üstünde bir iz bırakmış gibiydi: Göreceli olarak rahat bırakıldığı geceydi bu. (Faulkner (tr. Aytür) 2007: 169)

Horace goes to see Temple at the brothel and wants to learn the details about what happened at the Old Frenchman Place that night because he thinks Temple's statement could be helpful for Goodwin. During their conversation, Horace tries to guide her to tell the details about when and how the crime was committed but Temple evades this topic by talking about the previous night instead of the time of the crime.

The reader is never exposed to the details of the rape during Horace's encounter with Temple. Actually, the word 'rape' is never used in the novel. The reader is forced to use their imagination to fill in the gaps of the crime. Horace's in- vestigation is helpful for the reader but despite his guidance, details are blurry (Johnson 2014: 16-22).

T1 says 'kimsenin doğrudan doğruya saldırıya uğramadan geçirdiği gece' (the night which people spent without anyone being directly assaulted'). However, there is actually no one other than Temple who is a target for an assault. In $\mathrm{T} 2$, translation says 'kimsenin kendisine tecavüz etmediği o geceden' (the night when no one raped her). Using the word 'tecavüz' (rape) contradicts the blurry crime atmosphere created in the source text. The purpose is to talk about the crime as indirectly as possible because the reader is made uncomfortable with this vague language use. T3 keeps the language of the translation vague by saying 'Göreceli olarak rahat birakıldığı geceydi bu' (the night she was left in relative peace). Here the reader feels uncomfortable as they know that there is trouble waiting for Temple the following day. Also, the discomfort Temple feels while trying to remember is obvious in her narration because she intentionally avoids talking about what really happened. She says "It just happened. I don't know"(Faulkner 1931:258). So, in order to be coherent not only with the hidden details of the crime within the text, in general, but also to empathize with Temple's difficulty in talking about her experience, using vague language is important. And T3 seems to be the only one that has achieved this goal.

Example 4:

ST: 'I am not afraid,' Temple said. 'Things like that dont happen. Do they? They're just like other people. You're just like other people. With a little baby. And besides, my father's a ju-judge. The gu-governor comes to our house to e-eat--- What a cute littele bu-ba-a-by,'she wailed, lifting the child to her face; 'if bad mans hurts Temple, us'll tell the governor's soldiers, won't us?'

'Like what people?' the woman said., turning the meat. 'Do you think Lee hasn't anything better to do than chase after every one of you cheap little-' (Faulkner 1931: 64)

T1: 'Korkmuyorum' dedi Temple. 'Burda öyle şeyler olmaz değil mi? Bunlar da herkes gibi insan. Siz de öylesiniz, küçük bir çocuğunuz var. Hem üstelik babam yargıç. Vali evimize gelir, yemeğe kalır. Ne cici çocuk bu böyle' dedi çocuğu yüzüne doğru kaldırarak inledi. 'Eğer kötü adam Temple'e bir şey yapacak olursa, sen valinin askerlerine söylersin olur mu?

'Hangi ötekilerden söz ediyorsun?' dedi kadın, eti çevirerek. 'Sanıyor musun ki Lee'nin işi yok da sizin gibi...' (Faulkner (tr. Gürol) n.d.: 37)

T2: 'Korkmuyorum' dedi Temple. 'Öyle şeyler olmaz değil mi? Onlar da bizim gibi insan. Siz de ötekiler gibisiniz. Küçük bir de bebeğiniz var. Sonra babam da yargıç. Vali sık sık evimize gelir, yemeğe kalır... Ne kadar cici bir bebek.' Temple bebeği yüzüne doğru kaldırd1. 'Kötü adamlar Temple teyzeye bir şey yaparlarsa biz de valiye söyleriz değil mi?"

'Hangi adamlar?' diye sordu kadın eti çevirirken. 'yani Lee'nin işi yok da her önüne çıkan senin gibi adi...' (Faulkner (tr. Sunar) 1967: 56)

T3: 'Korkmuyorum' dedi Temple. Böyle şeyler olmaz. Öyle değil mi? Onlar da herkes gibi insan. Sizin herkesten bir farkınız yok. Küçük bebeğiniz filan. Üstelik ben- 
im babam da ya-yargıç. Vali bizim e-eve yemeğe gelir' dedi ağlamaklı bir sesle. 'Ne t-tatlı b-bebek!' dedi çocuğu yüzüne doğru kaldırarak. 'Kötü adamlay Temple'ın canını yakaysa biz de Vali’nin askeyleyine söyleyiz, değil mi?' dedi.

Kadın eti çevirirken, 'Kimden farkımız yokmuş?' diye sordu. 'Lee'nin senin gibi ucuz bir şıllığı her gördüğünde peşinden koşmaktan başka iși yok mu sandın?' (Faulkner (tr. Aytür) 2007: 49)

This conversation between Temple and Ruby is important as it gives us the opportunity to talk about an implied theme, otherization, in Sanctuary.

The artificial blackness ${ }^{6}$ is implied in this conversation with the word 'other'. When Temple says "They are just like other people. You are just like other people", she implies the distinction between the people at the Old Frenchman Place and the rest of the white community. With such an emphasis on their not being different, she actually vocalizes her inner voice about her perception of otherization. Ruby is too clever to miss that implication and therefore she asks, "What other people?". The conversation is a micro example of social positioning within the macro setting of the novel. Temple's insistence and repetition of her father's job as a judge is another sign of her perception of social positions and she somehow declares her superiority.

When we analyze the reciprocal awareness of 'us and them' between Temple and Ruby, we come up with the following findings. T1 says 'Hangi ötekilerden söz ediyorsun?' (Which others are you talking about?) while translating Ruby's question although it does not translate any words such as 'others' in Temple's speech. Temple says 'Bunlar da herkes gibi insan. Siz de öylesiniz, küçük bir çocuğunuz var' (These are human beings like everyone. So are you, you have a little kid). T2 says 'Hangi adamlar?' (Which guys?). Although this question makes sense in the flow of the conversation in the translation, this is not what Ruby asks Temple. Ruby's question in the source text refers to the previous part of Temple's speech where she compares the people in the speakeasy with people outside. She says 'Onlar da bizim gibi insan. Siz de ötekiler gibisiniz. Küçük bir de bebeğiniz var' (They are human beings just like us. You are like others. You have a little baby as well). The translation in this conversation misses the fact that Ruby recognizes the implication of otherization in Temple's speech and returns to that point for clarification. The reciprocal awareness of 'us and them' is found only in T3. In this translation Temple says 'Onlar da herkes gibi insan. Sizin herkesten bir farkınız yok. Küçük bebeğiniz filan’ (They are just like everyone. You are not different from anyone. With a little baby). The use of 'herkes' (everyone) here functions like 'others' in the source text. It covers the intention of otherization semantically but still implies the difference and discrimination. In return, Ruby asks 'Kimden farkımız yokmuş?' (We are no different from who?) which can be another way of asking 'Who are we like?'. T3 manages to preserve the implication of social positioning in the ST and stands out among the translated texts.

C) Expansion

This tendency which is a result of the two former tendencies is also called 'overtranslation' because the translation has additions. Berman thinks that quantitative additions to the original work have no qualitative value. The expansion which seems to make the text clearer is actually meaningless additions (2000: 290).

Using culture specific vocabulary is the common tendency for the expansion of the translation in the following examples.

Example 5:

ST: 'Served him right.' The driver said. 'We got to protect our girls. Might need them ourselves.' (Faulkner 1931: 357)

T1: 'İyi oldu' dedi şoför. 'Kızlarımızı korumalıyız, kendimize gerekir.' (Faulkner (tr. Gürol) n.d.: 185)

T2: 'Hak etmişti' dedi Şoför. 'Kızlarımızın namusunu korumamız gerek. Bizim onlara ihtiyacımız olacak.' (Faulkner (tr. Sunar) 1967: 270)

T3: 'Layığını bulmuş. Kızlarımızı korumalıyız. Bize de gerekebilir onlar.' (Faulkner (tr. Aytür) 2007: 231)

In Example 5, T1 and T3 translate 'We got to protect our girls' as 'Kızlarımızı korumalıyız'. However, T2 annotated the translation by adding the word 'namus'. This word is used in a gender specific context and refers to women's honor and virginity.

Example 6:

ST: 'It better not born at all,' she said. 'None of them had.' (Faulkner 1931: 253)

T1: 'Doğmasa daha iyi olurdu,' dedi. 'Hiçbiri doğmasaydı keşke.' (Faulkner (tr. Gürol) n.d.: 132)

T2: 'Keşke hiç doğmasalardı şu piçler.' (Faulkner (tr. Sunar) 1967: 191)

T3: 'Keşke o çocuk hiç doğmasaydı,' dedi. 'Hiçbiri doğmasa.' (Faulkner (tr. Aytür) 2007: 166)

In Example 6, T1 and T3 translate 'None of them' as 'Hiçbiri'. However, another annotation in T2 refers to a culture specific issue as well. The word 'piç' means a child without a father. In the target culture, bearing a child without a father is considered as the woman's fault and the blame is put on the mother for having an illegitimate child.

Example 7:

ST: There was a girl went abroad one summer that told me about a kind of iron belt in a museum a king or something used to lock the queen up in when he had to go away. (Faulkner 1931: 261)

T1: Geçen yaz Avrupa'ya giden bir kız söylemişti, müzelerin birinde gördüğü demir bir kemerden söz etmişti, kral mı ne, biri yolculuğa çıkınca kraliçesi o kemeri takarmış. (Faulkner (tr. Gürol) n.d.: 135)

T2: Geçen yaz bir arkadaşım Avrupaya gitmişti. O anlatmıştı. Bir müzede demirden bir bekaret kemeri görmüş. Kral yahut bir başka erkek uzağa gideceği zaman karısına bu kemeri takarmış. (Faulkner (tr. Sunar) 1967: 196)

T3: Yazın yurtdışına giden bir kız vardı, o anlatmıştı, müzede demirden bir çeşit kemer varmış, bir memleketin kralı bir yere gitmesi gerekince kraliçeye bunu takar, kilitlermiş. (Faulkner (tr. Aytür) 2007: 171)

In Example 7, T1 and T3 translate 'iron belt' as 'demirden bir kemer'. T2 uses the expression 'bekaret kemeri' to refer to the iron belt because this is the Turkish word for 'chastity belt' and once again, it is associated with the wom- 
an's honor and seen as a means to prevent her from having intercourse with other men.

D) Qualitative Impoverishment

The translation is carried out in such a way that the target text expressions do not correspond to the source text expressions in terms of richness and density. Berman thinks that " $A$ term is iconic when, in relation to its referent, it creates an image, enabling a perception of resemblance" (2000: 291).

Example 8:

ST: Put a beetle in alcohol, and you have a scarab; put a Missisipian in alcohol, and you have a gentleman. (Faulkner 1931: 29)

T1: Alkolün içine küçük bir bok böceği at, alsana koskoca bir bok böceği. Alkolün içine tutup bir Missisipili at, al sana bir centilmen. (Faulkner (tr. Gürol) n.d.: 20)

T2: İçkinin içine bir bok böceği koy, al sana bir bok böceği, içkinin içine bir Missisipili at, al sana bir centilmen. (Faulkner (tr. Sunar) 1967: 30)

T3: Sıradan bir böceği alkole yatırın, Mısırlıların kutsal bok böceğini elde edersiniz; bir Missisipiliyi alkole yatırın beyefendi olur çıkar. (Faulkner (tr.Aytür) 2007: 27)

This metaphor has two functions for the reader to understand who Gowan really is. First, it displays the difference between Gowan's self-esteem and what others really think of him. Secondly, the transformation the beetle experiences is similar to how Gowan changes under the effect of alcohol. Therefore, the metaphor that centers around the character who started all the trouble for Temple is important to understand why Gowan did what he did.

Horace meets Gowan at his sister, Narcissa's house before the Friday night when Gowan takes Temple to the college dance. Before their encounter, while Miss Jenny - Narcissa's late husband's aunt- and Horace are at the window watching Narcissa and Gowan walking in the garden, they talk about Narcissa and why she did not marry again. Horace objects to the idea of his sister marrying Gowan and thinks that his sister is interested in Gowan because "she seems to like children" (Faulkner 1931: 25-26).

On his encounter with Horace at Narcissa's house, Gowan is described as a man "with sleek head, plump, assured face". He bends and kisses Miss Jenny's hand, compliments her on her appearance and talks to Horace as a mature, young man (Faulkner 1931: 29). He acts on a certain set of rules called 'etiquette and politeness'.

This polite, well-behaved character becomes out of control when it comes to drinking. He starts drinking with three town boys after he drops Temple off at the college dorm. He claims to have learnt how to drink at a good school (Faulkner 1931: 38) and boasts about it. His obsession with drinking is the reason why he and Temple head for The Old Frenchman Place and get into trouble after Gowan crashes his car as they approach the distillery.

Under the influence of alcohol, he acts in an irrational way. He keeps drinking and falls asleep with no thought of protecting Temple. Moreover, when he wakes up the next morning, he leaves home hoping to find a car and drive Temple back to school. However, as time goes by, he remembers the details of the previous night and realizes that he can't bear to face Temple again so he leaves her there all alone.
The Missisipian, who becomes a gentleman under certain conditions, goes back to his origins with this final decision of being selfish in order not to bear the consequences of his actions.

T1 and T2 cannot make the connection between the transformation of a beetle and Gowan under the influence of alcohol. T1 says the beetle would become 'kocaman' (huge) however the transformation is not about growing in size. T2 does not even mention any word of change and the beetle remains the same. The implication of this metaphor is obvious only in T3. Just like a beetle turns into a scarab (Misırlıların kutsal bok böceği); a Missisipian turns into a gentleman (beyefendi). The metaphor with this translation in $\mathrm{T} 3$ is in coherence with the rest of the depiction of Gowan's character within the book and acts as a flashforward to give a clue about who Gowan really is and how he will behave. While translating this metaphor, T3 is the only one that has avoided the deforming tendency of quantitative impoverishment.

E) The Destruction of Underlying Networks of Signification

Beneath the main text, a sub-text is created with certain substantives and they form a network which makes sense within its own context. Each word may not be significant by itself, but when used together, their network has a value as a subtext. Berman believes that if such a chain of words is overlooked, the text is seriously destroyed (2000: 293).

Example 9:

ST: 'You poor bastard,' the first said.

'Am I?' the second said. He took something from his pocket and flipped it out, whipping the sheer, faintly scented web across their faces. "Am I?"

'That's what you say.'

'Doc got that step-in in Memphis,' the third said. 'Off a damn whore.' (Faulkner 1931: 34)

T1: 'Piç sen de' dedi birincisi,

'Ya!' dedi ikincisi. Cebinden bir şey çıkardı ve burunlarına doğru kokulu bir eşarp şaklattı. 'Piç ha?'

'Kendi ağzınla söylüyorsun işte.'

'Doc bu piçi Memphis’te bulmuş' dedi üçüncüsü, 'kaşarlanmış bir orospudan almış.' (Faulkner (tr. Gürol) n.d.: 22) T2: İlki, 'Piç,' dedi.

'Ben mi?' dedi ikincisi. Cebinden bir şey çıkardı. Hafifçe kokulu, incecik eşarbı yüzlerine doğru salladı. 'Ben mi?'

'Doc bunu Memphis'de bulmuş,' dedi üçüncüsü, 'kaşarlanmış bir orospudan.' (Faulkner (tr. Sunar) 1967: 33)

T3: Birinci genç, 'Sen zavallının tekisin,' dedi.

'Ne zavallısı?' dedi ikinci çocuk. Cebinden bir şey çıkardı; bu hafif kokulu, ince kumaşı arkadaşlarının yüzünde şaklattı, 'Ben mi zavallıymışım?' dedi.

'Senin sözüne mi inanacağız yani?'

Üçüncü çocuk, 'Doc bu donu Memphis'te bir orospudan almış,' dedi. (Faulkner (tr. Aytür) 2007: 31)

This conversation takes place among three town boys watching Temple and Gowan Stevens come out of the Letter Club. They are jealous of Gowan as he accompanies Temple, whom they are familiar with. Then, they start to mock one boy in the group as they do not believe the story about his affairs. The boy's implied affair with a whore in Mem- 
phis functions like a sub-text within the main context where Gowan drives away with Temple.

There are two key words in this conversation: 'web' and 'step-in'. T1 and T2 translate 'web' as 'eşarp'. But 'eşarp' refers to a very specific type of fabric which means 'scarf' in Turkish; however 'web' means a piece of woven fabric. The correspondence is given in T3 with the word 'kumaş'. 'Step-in' has been translated as 'bu piçi' (this bastard) in T1 and there is an obvious confusion here. In T2 it is translated as 'bunu' (this) and it is not clear what the pronoun 'bunu' refers to as the previous sentences in the conversation have been omitted. In T3 it has been translated as 'don' which means 'underwear' so that the flow of communication is not interrupted. Doc probably claims that the step-in is a souvenir that remains from a previous instance of intercourse and shows it off to his friends.

It is important to understand this dialogue because it helps the reader to gain insight into how Temple is perceived. In her article entitled "Sanctuary, Sexual Difference and the Problem of Rape", Linda Dunleavy claims that Temple is gender-neutral with her physical appearance and her name. Femininity has got nothing to do with her long legs, thin arms and need of protection like a child. What makes her a woman is her make-up, high-heels and nice clothes (1996:175).

This conversation is important for the reader to draw the right image of gender perception within the novel. While Temple's effort to look like a woman is given through her high-heeled shoes and powdered face, her childish manner is obvious because she is in search of protection throughout the novel. Her physical appearance functions as imagery for the socially constructed gender roles. For the target reader to ascertain how Temple is regarded as a female figure, clothing has a symbolic function. That is why the step-in, which does not even belong to Temple, comes into the scene while she drives away. What makes a woman is how men perceive them in terms of clothing and physical appearance. This female imagery is available only in T3.

F) The Destruction of Expressions and Idioms

Berman thinks that a proverb may have an equivalent in another language but he emphasizes that finding an equivalent does mean translating a proverb (2000: 295). Images, expressions, figures and proverbs require more than searching for equivalences. A literal translation which is foreign but complementary for the target language is recommended.

Example 10:

ST: That big pie-face-ted man left it fer $^{7}$ him. (Faulkner 1931: 249)

T1: Şu şişko, pasta suratlı herif verdi. (Faulkner (tr. Gürol) n.d.: 129)

T2: Şu şişko, pasta suratlı herif verdi. (Faulkner (tr. Sunar) 1967: 188)

T3: O ekmek hamuru suratlı koca herif gönderdi. (Faulkner (tr. Aytür) 2007: 164)

In this example the person who is described as pie-faceted is Senator Snopes. He sees Horace entering Miss Reba's brothel, stops him and refers to Horace's manly needs and promises to keep this secret safe with him. Horace, who is at the brothel to talk to Temple, does not care and goes into the house. Then, Snopes sends him a note on which the address of a black whore-house is written. The servant at Miss Reba's brothel, Minnie, brings the note to Horace.

The idiom 'pie-faced' means 'having a broad, flat face, and sometimes, a vacuous or stupid expression' ("piefaced"). T1 and T2 have taken a source text approach and translated the idioms literally. However, T3 has used a different expression as 'bread dough faced' (hamur suratli).

In Turkish language, the idiom 'ekmek kafalı' (bread headed) is used as an insulting expression for people whose diet consists mainly of carbohydrates and thus these people are believed to be not so clever. T3 has reformed this expression by saying 'bread dough faced' so that it implies the cultural assumption while preserving the function within the source text.

Example 11:

ST: She will be on the streets again, and God only knows what will become of that baby. (Faulkner 1931: 253)

T1: Yine yollara düşecek, çocuğun geleceğinin ne olacağını da Tanrı bilir. (Faulkner (tr. Gürol) n. d.: 131)

T2: Tekrar sokağa düşecek. Çocuğun ne olacağını da Allah bilir. (Faulkner (tr. Sunar) 1967: 191)

T3: Gene sokaklara düşecek. O çocuğa ne olacağını da ancak Tanrı bilir. (Faulkner (tr. Aytür) 2007: 166)

Horace is talking to Miss Reba about Ruby to persuade her to let him see Temple. He is trying to inform Miss Reba about the consequences of this legal case. The idiom 'to be on the streets' has been mistranslated in T1 as 'to hit the road' (yollara düşmek). However, retranslations have corrected this error by translating 'to be on the streets' as 'sokağa düşmek' and managed to give the corresponding meaning. In Turkish 'sokağa düşmek' is used only for women who work as prostitutes. The possible future summarized for Ruby with the sentence "She will be on the streets" corresponds to the Turkish expression 'sokağa düşecek' as in T2 and T3.

Example 12:

ST: “... Lee says hit wont hurt you none. All you got to do is lay down..." (Faulkner 1931: 118)

T1: “... Lee senin kılına bile dokunmıyacaklarını söylüyor. Sen yat uyu.” (Faulkner (tr. Gürol) n.d.: 63)

T2: “... Lee senin kılına bile dokunmıyacaklarını söylüyor. Sadece sen yat uyu..." (Faulkner (tr.Sunar) 1967: 96)

T3: “... Lee diyor ki hiç canın acımayacağmış. Sen yatacan o gadar..." (Faulkner (tr. Aytür) 2007: 81)

Tommy is trying to calm down Temple who is hiding in the barn to avoid Goodwin and Popeye. As Goodwin and Popeye are in search of Temple, he tries to keep her out of trouble but he cannot fully understand what the other two men intend to do. His expression 'hit wont hurt you' has been translated as 'k1lına bile dokunmayacaklarını' (they will not touch a hair on your head). This idiom means she will get away without being harmed. However, this is not exactly what Tommy promises. Goodwin does not intend to let Temple get away before he gets what he wants. Tommy implies that it will be pain-free if she does not resist and the corresponding idiom to express this can be found in T3 which says 'canın acımayacak' (it won't hurt). 
G) The Effacement of the Superimpositions of Languages

This tendency involves the relation between a dialect and a common language and their co-existence within the text. Berman thinks that the diversity of languages and voices should be preserved in the translation because such diversity helps us to understand the relation between the underlying language and the surface language. Preserving the diversity of language use also prevents the translation from sacrificing the foreignness of the text (2000: 296-297).

Example 13:

ST: ‘...... And besides, my father's a ju-judge. The gu-governor comes to our house to e-eat--- What a cute littele bu-ba-a-by,'she wailed, lifting the child to her face; 'if bad mans hurts Temple, us'll tell the governor's soldiers, won't us?' (Faulkner 1931: 64)

T1: '.... Hem üstelik babam yargıç. Vali evimize gelir, yemeğe kalır. Ne cici çocuk bu böyle' dedi çocuğu yüzüne doğru kaldırarak inledi. 'Eğer kötü adam Temple'e bir şey yapacak olursa, sen valinin askerlerine söylersin olur mu?' (Faulkner (tr. Gürol) n.d.: 37)

T2: '.... Sonra babam da yargıç. Vali sık sık evimize gelir, yemeğe kalır... Ne kadar cici bir bebek.' Temple bebeği yüzüne doğru kaldırdı. 'Kötü adamlar Temple teyzeye bir şey yaparlarsa biz de valiye söyleriz değil mi?' (Faulkner (tr. Sunar) 1967: 57)

T3: '.... Üstelik benim babam da ya-yargıç. Vali bizim e-eve yemeğe gelir' dedi ağlamaklı bir sesle. 'Ne t-tatlı b-bebek!' dedi çocuğu yüzüne doğru kaldırarak. 'Kötü adamlay Temple'ın canını yakaysa biz de Vali'nin askeyleyine söyleyiz, değil mi?' dedi.' (Faulkner (tr. Aytür) 2007: 49)

In this part of the novel, Temple and Ruby are in the kitchen and Temple complains about her date, Gowan, and how they ended up at the Old Frenchman Place. While Ruby prepares dinner, Temple wants to hold the baby that his mother, Ruby, normally keeps in a box in the kitchen to protect him from the rats.

This conversation sheds light on how Temple identifies with the baby. As she feels threatened with these men around, she escapes to the kitchen and talks to the baby to reassure herself that she is not and will not be in trouble. Her immaturity comes to light as she holds the baby like a child holding a doll. In short, the baby functions both as a double and a doll for Temple (Kirchdoerfer 2015: 125-127).

In T1 and T2, there is no sign of Temple's frightened mood or empathy towards the baby. However, T3 takes a different stand and translates the repetitive utterances as they are in the ST so that the target reader has a clear understanding of how the main character really feels although, previously, she had told Ruby that she was not frightened. Moreover, in the second part of the conversation, words such as 'adamlay, yakaysa, askeyleyine, söyleyiz’ were consciously misspelled with the letter '-y' instead of '-r' because in Turkish, children mainly cannot produce the '-r' sound and use '-y' instead. Under normal circumstances, the correct spelling of these word would be 'adamlar, yakarsa, askerlerine, söyleriz'. It is possible to say that the translator of T3 has decided to misspell these words to show how immature Temple can be and can play with the baby as if it were a doll. In short, in T3, the translator's decisions have proven to follow the functions of the conversation in the ST.

Examples 14 and 15 are two examples of two different characters speaking broken English.

Example 14:

ST: 'Who drives the truck?' Benbow said. 'Some more Memphis fellows?'

'Sho' Tommy said. 'Hit's Popeye's truck.'

'Why cant those Memphis folks stay in Memphis and let you all make your liquor in peace?'

'That's where the money is,' Tommy said. 'Aint no money in these here piddlin little quarts and half-a-gallons. Lee just does that for a-commodation, to pick up a extry dollar or two. It's in making a run and getting shut of it quick, where the money is.' (Faulkner 1931: 23)

T1: 'Kim sürüyor kamyonu?' dedi Benbow 'Memphisliler mi yine?'

'Kim olacak, Popeye'ın kamyonu tabi.'

'Ne diye şu Memphisliler yerinde duramazlar da, size kendi halinize bırakmazlar bir türlü.'

'Para onlarda da ondan' dedi Tommy. 'Burada birkaç litre bile tutmaz yapılan iş. Iş olsun diye yapıyor bunu Lee. İnsan, iş yapınca yapar yapmaz devretmeli malı, tüketmeli, süratle yapmalı, böyle para kazanılır.' (Faulkner (tr. Gürol) n.d.:16)

T2: 'Kamyonu kim kullaniyor?' diye Benbow sordu, 'Memphis'lilerden biri mi?'

'Kamyon Popeye'nin.' dedi Tommy.

'Niçin bu Memphis'liler Memphis'te kalıp da sizin rahat rahat içki yapmanıza meydan vermiyorlar?'

'Bu işte para var da ondan.' diye Tommy cevap verdi. 'Yapılan iş burada birkaç litre bile tutmaz. Sırf iş olsun diye yapıyor bunu Lee. Fazladan bir iki kuruş kazansın diye. İnsan bir iş yaptı mı derhal elinden çıkarmalı. Para böyle kazanılır.' (Faulkner (tr. Sunar) 1967: 25)

T3: 'Kamyonu kim sürüyor?' dedi Benbow. 'Gene Memphisli birtakım adamlar mı bunlar?'

'He ya. Gamyon Popeye'in gendi gamyonu.'

'Neden Memphisliler yerlerinde oturup sizi rahat rahat içkinizi yapmaya bırakmazlar?'

'Para onlarda da ondan. Çeyreklik, yarım galonluk güççük şişelerle para kazanılmaz. Lee bunu hatır için yapıyor; fazladan bir iki dolar gazanmak için. Asıl para büyük parti içkiyi elden çıkarmakta.' (Faulkner (tr. Aytür) 2007: 23)

Example 15:

ST: 'Well, Judge,' he said. 'I hear you're having some trouble gitting a boarding-place for that client of yourn. Like I always say-" he leaned, his voice lowered, his mud-colored eyes roving aside "-the church aint got no place in politics, and women aint got no place in neither one, let alone the law. Let them stay at home and they'll find plenty to do without upsetting a man's law suit. And besides, a man aint no more than human, and what he does aint nobody's business but his. What you done with her?' (Faulkner 1931: 223-224)

T1: 'Vay, yargıç bey,' dedi, 'işittiğime göre, şu sizin müşteri için epey zorluk çekmişsiniz, yatacağı bir yer arayıp durmuşsunuz; hep derim..." Eğildi, sesi alçaldı, çamur rengi gözleri fırıl fırıl dönüyordu. “... Kilisenin siyasette yeri 
yoktur; hele kadınların kanun bir yana, ne kilisede yerleri vardır, ne siyasette. Kadınlar evde kalmalıdırlar, erkeğin işine burnunu sokmadan bir sürü yapacak iş bulurlar kendilerine. Erkek ne de olsa bir insan alt tarafı, yaptığı iş de kendinden başka hiç kimseyi ilgilendirmez. Bir şey yapabildiniz mi bari, kadın için?' (Faulkner (tr. Gürol) n.d.:116)

T2: 'Merhaba yargıç' dedi, 'İşittiğime göre şu müşteriyle başınız bir hayli derde girmiş. Ona yatacak yer bulamamışsınız. Her zaman dediğim gibi...' Snopes öne doğru eğildi. Sesini alçalttı. Çamur rengi gözleri firıl firıl dönüyordu. ‘... Kilisenin siyasetle uğraşması hiç hoş değil, hele kadınların her iki yerde de gereği yoktur. Tabii kanun başka. Evlerinde otursunlar. Bir adamın işini karıştırmaktan başka yapılacak iş bulurlar herhalde. Hem sonra erkek bile olsa, o da insan. Yaptıkları da kendisinden başka kimseyi ilgilendirmez. Kadın için bir şey yapabildiniz mi bari?' (Faulkner (tr. Sunar) 1967: 169-170)

T3: 'Ee, yargıç,' dedi Snopes. 'Duyduğuma göre şu müşterinize galacak yer bulmakta güçlük çekiyomuşsunuz. Hep derim ki'- eğildi, sesini alçalttı, çamur renkli gözleriyle sağ1 solu kollad1, '- kilisenin siyasete bulaşması doğru deel, gadınların ikisinde de yeri yok, ganunlara heç garışamaz onlar. Otursunlar evlerinde, yapacak o gadar işleri varken erkeğin davasına çomak sokmak nelerine. Üstelik, erkek de sonuçta insandır, ne yaptığı yalnız gendini ilgilendirir. Gadını ne yaptınız?' (Faulkner (tr. Aytür) 2007: 146)

The person talking in example 14 is Tommy, a bootlegger. The one in the $15^{\text {th }}$ example is Senator Clarence Snopes, who was, according to Horace, the dull son of a restaurant owner and had a family big enough to have votes to elect him (Faulkner 1931: 210). Tommy and Snopes have one thing in common: they are not considered to be so white and their language use is a sign and proof of their social status, which implies black-white racism. Doreen Fowler, summarizes the examples of this "nearly invisible black community" as follows:

Popeye, for example, is himself a black figure. In his tight, black suits, he is repeatedly described as "black" (42, 49, 109; Sanctuary: The Original Text 9). Miss Reba's white brothel is shadowed by the black brothel that Clarence Snopes favors for its reasonable rates. And, in a scene that Faulkner positioned as the first chapter of the original text, Lee Goodwin, in his jail cell, nightly listens to the doomed black man in the next cell, his black double, who sings of a certain death that betokens Lee's own. Narcissa even anticipates a joint hanging: "Maybe they'll wait and hang them both together. They do that sometimes, dont they?" (134). Most pointedly, the pressure to alienate this not-so-white underclassRuby cannot stay in Horace's house nor in the town hotel, and Narcissa is outraged that Horace would "mix [him]self up" with such people (117) — subliminally figures the racial segregation that historically characterizes Faulkner's South. (2004: 422)

Characters' use of language is certainly a part of their representation. Within the context of Sanctuary, where the reader faces an implied white-black discussion, language use adds to the characters' social representation. This social clue is given in T3 to provoke the reader to think about artificial blackness. However, there is no sign of it in T1 and T2. T3 manages to give these lower class language signs by using the '-g' sound instead of ' $-\mathrm{k}$ ', misspelling words such as 'güççük', when the correct spelling would be küçük (small), and 'deel' instead of değil (negation of the sentence). Such broken use of Turkish language may have two implications: First, it is possible to say that the people who use such dialectical language, which is mostly observed in central and rural parts of Anatolia, deviate from standard Turkish language pronunciation. Secondly, this language use may indicate lack of education or a lower social class. These implications about characters, which are of great significance if we are to better understand the novel, are only available within the dialogue translations of T3.

\section{FINAL REMARKS BASED ON A BERMANIAN READING OF THREE TRANSLATIONS OF SANCTUARY}

Based on our research, we discovered examples of 7 deforming tendencies, namely; rationalization, clarification, expansion, qualitative impoverishment, the destruction of underlying networks of signification, the destruction of expressions and idioms and the effacement of the superimpositions of languages.

The two examples given for rationalization show that $\mathrm{T} 1$ and T2 generalize the translation of two words 'men and boys' as 'people'. T3 is the only translation that avoids such a decision. The idea of generalization within these two examples obscure the theme of socially constructed gender imagery. The theme of socially constructed gender imagery is important because throughout the novel women live in a "sanctified world" (Urgo 1983:437) created by men. Their dependence on the male gender is obvious, especially in the lives of two female characters: Temple and Ruby.

The clarification in example 3 acts against Faulkner's writing style. The central event in the novel is Temple's rape but it is revealed without being explicitly named by the author. T1 uses the word 'assault' while T2 uses the word 'rape'. T3 is the only version which is careful with the wording of the narration in the source text. The other clarification in example 4 reveals the theme of otherization. The people at the Old Frenchman Place are not black but the way they are portrayed and treated leads to the discussion of 'artificial blackness' as a theme within the novel. The comparison of social status is implied only in T3 as in the source text.

The deforming tendency of expansion is exemplified by T2 in three instances. T2 has a tendency towards a target culture-oriented translation in examples 5, 6 and 7 and the tendency of expansion in these examples is revealed through the use of culture specific vocabulary such as namus (female virginity), piç (an illegitimate child without a father), bekaret kemeri (chastity belt). The tendency in T2 puts a cultural emphasis on gender roles through expansion. T1 and T3 have translated these words without cultural references.

Example 8 is a metaphor where the translation undergoes the deforming tendency of qualitative impoverishment. The translation of this metaphor is important to understand the male character who lost his control under the effect of alco- 
hol and started the chain of events. The change in Gowan's character as a male character is important to see the irony in other male characters as well. Horace looks like a decent man despite having some interest in his step-daughter. Popeye gives the impression of a macho gangster but, in reality, he is impotent and is not even considered as a real man. Lee acts like a fearless bootlegger but is afraid to give testimony against Popeye because he is scared that Popeye would kill him. T3 is distinct in that it is the only translation in which this metaphor is used.

The destruction of underlying networks of signification is exemplified in the conversation in example 9. The subtext created with the words 'poor bastard', 'web', 'step-in' and 'whore' informs the reader about the sexual image of the woman. Clothing is an essential part of female image and this image is created by the male members of the society. The conversation among three town boys is a concrete example of this imagery and this image is fully described only by T3.

In example 10, the idiom 'pie-faceted-man' has been literally translated in $\mathrm{T} 1$ and $\mathrm{T} 2$. However, T3 has translated it by reshaping a corresponding expression in the target language, and still preserves the original function of the expression. Therefore, although the wording is different, the foreign remains as it is. In example 11, the idiom 'to be on the streets' has been mistranslated as 'to hit the road' in T2 and $\mathrm{T} 3$ despite the fact that there is an equivalent idiom in Turkish. In Example 12, T3 is the only translation that gives the corresponding meaning. The former two translations lead the reader to think that the rape might not take place.

Examples 13, 14 and 15 have been taken from conversations which give a significant amount of information about the characters in terms of feelings, background and social status. However, the pronunciation deformations are available only in T3 while the effacement of the superimpositions of languages is observed in T1 and T2. The omission of specific language usage in translation makes it hard to understand characters' roles and social positions.

\section{CONCLUSION}

The novel Sanctuary by William Faulkner sets an example of the fact that texts are shaped and reshaped by the politics and poetics of their context. A rewriting process of the original text was requested by the editor and carried out by the author himself to make the text acceptable in the source culture. Within the scope of this research, whose theoretical framework is based upon the reading of the French translation studies scholar Antoine Berman, we have analyzed 'the trial of the foreign' in the translation process of this revised text. Analyzing the three Turkish translations of the source text by three different translators, the paper questions how the text became acceptable for the target culture with each translation, translators' awareness of 'deforming tendencies' and the effects of translators' decisions on the final outcome of every translation process.

The fact that Sanctuary is the only novel by William Faulkner with three Turkish translations has sparked the discussion in this study. The first translation decision that attracted out attention was the titles of the translations be- cause they are completely unrelated. With an aim to finding out what other different translation decisions might be given within the three texts, we have made a textual comparison. Seven out of twelve deforming tendencies - rationalization, clarification, expansion, qualitative impoverishment, the destruction of underlying networks of signification, the destruction of expressions ad idioms and the effacement of the superimpositions of languages - have been exemplified within the frame of this textual comparison.

Based on the findings, although the translator of the latest translation seems to be fully aware of the deforming tendencies and, as a result, cautious about the decisions she has made, it is possible to say that different types of deforming tendencies are available at different levels in all three translated texts. It is also possible to say that these tendencies are observable, especially when themes such as socially constructed gender roles, sexuality, otherization and social classes are in question. As a matter of fact, it can be concluded that, just as Berman emphasized, these examples of deforming tendencies deprive the target text reader of the essential discussions within the source text. Therefore, the basic themes in Faulkner's source text, which have been discussed within the scope of this research, have experienced 'the trial of the foreign' in Turkish literature and the translators have tended to eliminate the foreignness of the source text.

\section{ACKNOWLEDGEMENTS}

This article is based on the $\mathrm{PhD}$ dissertation of the first author submitted to Y1ld1z Technical University, İstanbul, Turkey. The second author is the advisor of the $\mathrm{PhD}$ dissertation.

\section{END NOTES}

1. In 1972, The University of Texas Press published an edition of the unrevised manuscript. However, the original text became easily accessible for more people after Sanctuary: The Original Text was published in 1981.

2. This translation was later published by Cem Publishing House. The copy used in this research belongs to this publishing house but the date is not given.

3. ST: Sanctuary T1: Kutsal Siğınak (Holy Shelter) T2: Lekeli Günler (Stained Days) T3: Tapınak (Temple)

4. Paratexts such as prefaces, forewords, afterwords provide information about translation processes during which translators make certain decisions while there are various alternatives. These decisions are clarified with reasons in the paratexts of translations and it is for this reason that Gerard Genette's study of paratexts in his book Seuils (1987) attracted so much attention in translation studies to explain why and how such decisions are made.

5. For a sense of paratext related research carried out in the context of Translation Studies, see Eshabil Bozkurt\& Ayşe Banu Karadağ 2014; Gil Bardaji 2012; Hartama-Heinonen 1995; Lütfiye Oktar \& Neslihan Kansu Yetkiner 2012; Rodica 2009.

6. The theme of 'artificial blackness' will be discussed in a detailed way with examples $14 \& 15$ under the title of 
The Effacement of the Superimpositions of Languages.

7. This is not a grammatical mistake. It has been copied from the source text.

\section{REFERENCES}

Berman, Antoine. "La Retraduction Comme Espace de Traduction." Palimpsestes 4 (1990): 1-7.

Berman, Antoine. "Translation and the Trials of the Foreign." The Translation Studies Reader. Ed. Lawrence Venuti. London: Routledge, 2000. 284-87.

Birkan Baydan, Esra. "Editing as Rewriting." I. Ü. Çeviribilim Dergisi/I.U Journal of Translation Studies 3. (2011): n. pag. Web. 13 January 2017.

Bozkurt, Eshabil \& Ayşe Banu Karadağ. "II. Meşrutiyet'ten Harf Devrimine Kadar Yapılan Osmanlıca Roman Çevirilerinin Süreç Öncesi Normlar Bağlamında İrdelenmesi." Humanitas International Journal of Social Sciences 3 (2014): 85-104.

Dunleavy, Linda. "Sanctuary, Sexual Difference and the Problem of Rape." Studies in American Fiction 24.2 (1996): 171-91.

Faulkner, William. Sanctuary. New York: Random House, 1931.

Faulkner, William. Kutsal Sığınak. Trans. Ender Gürol. İstanbul: Cem Yayınları, 1961.

Faulkner, William. Lekeli Günler. Trans. Özay Sunar. İstanbul: Altın Kitaplar, 1967.

Faulkner, William. Tapınak. Trans. Necla Aytür. İstanbul: Yapı Kredi Yayınları, 2007.

Fawler, Doreen. "Faulkner's Return to the Freudian Father: Sanctuary Reconsidered." Modern Fiction Studies 50. 2 (2004): 411-34.

Genette, Gérard. Seuils. Paris: Editions du Seuil, 1987.

Gil Bardaji, A, et al. Translation Peripheries: Paratextual Elements in Translation. Berlin: Peter Lang, 2012.

Hartama-Heinonen, Ritva. “Translators' Prefaces: A Key to Translation?.” Folia Translatologica 4 (1995): 33-42.

Irwin, John T.. "Horace Benbow and the Myth of Narcissa." American Literature 64. 3 (1992): 543-66.

Jaillant, Lise. Modernism, Middlebrow and the Literary Canon: The Modern Library Series, 1917-1955. Lon-
don/New York: Routledge, 2016.

Jakobson, Roman. "On Linguistics Aspects of Translation." On Translation. Ed. R. A. Drawer. Cambridge, MA: Harvard University Press, 1959. 232-39.

Johnson, Amanda R.. "Nothing Is as It Seems: Reading Deviance in Faulkner's Sanctuary and McCullers' Reflections in a Golden Eye." Diss. Middle Tennessee State University, 2014.

Kirchdorfer, Ulf. "Temple Drake and the Baby in William Faulkner's Sanctuary." ANQ: A Quarterly Journal of Short Articles, Notes and Reviews 28.2 (2015): 125-27.

André. Translation, Rewriting and the Manipulation of Literary Frame. London \& New York: Routledge, 1992.

McDonald, Hal. "Faulkner's Sanctuary." Explicator 55. 4 (1997): 222-23.

McRae, Ellen. 2010. "The Role of Translators' Prefaces to Contemporary Literary Translations into English." Diss. The University of Auckland, 2010.

Munday, Jeremy. Introducing Translation Studies: Theroies and Applications. London: Routledge, 2001.

Oktar, Lütfiye \& Neslihan Kansu Yetkiner. "Different Times, Different Themes in Lady Chatterley's Lover: a Diachronic Critical Discourse Analysis of Translator's Prefaces." Neohelicon, ACTA Comparationis Litterarum Universarum 39. 2 (2012): 337-64.

"Pie-faced." Dictionary.com Online. Random House Unabridged Dictionary. Web. 20 April 2017.

Phillips, Gene D.. Fiction, Film and Faulkner: The Art of Adaptation. Knoxville: The University of Tennessee Press, 1988.

Rodica, Dimitriu. “Translators' Prefaces as Documentary Sources for Translation Studies." Perspectives Studies in Translatology 9.17 (2009): 193-206.

"Sanctuary." Cambridge Dictionary Online. Cambridge University Press, 2016. Web. 19 January 2017.

Urgo, Joseph R.. "Temple Drakes Truthful Perjury: Rethinking Faulkners Sanctuary." American Literature 55. 3 (1983): 435-44.

Venuti, Lawrence. The Scandals of Translation: Towards and Ethics of Difference. London/New York: Routledge, 1999. 